\title{
PCR verification of microplate phenotypic system identification for LAB from traditional Western Balkan raw milk cheeses
}

\author{
doi: $10.15567 /$ mljekarstvo.2014.0403 \\ Diana Paveljšek ${ }^{1 *}$, Aljoša Trmčićn ${ }^{1}$ Biljana Hacin², Irena Rogelj1 \\ ${ }^{1}$ Department of Animal Science, Biotechnical Faculty, University of Ljubljana, \\ Groblje 3, SI-1230 Domžale, Slovenia \\ ${ }^{2}$ National Veterinary Institute, Veterinary Faculty, University of Ljubljana, \\ Pri Hrastu 18, SI-5000 Nova Gorica, Slovenia
}

Received - Prispjelo:28.02.2014. Accepted - Prihvaćeno: 12.09.2014.

\begin{abstract}
Fermentation and ripening specificity of traditional cheeses are predominantly directed by the natural microbial community present in milk selected by the cheese-making environment and technology. Therefore the traditional cheeses are unique products with specific microbiota biodiversity. There are several approaches for the identification of microbial population, however all of them have certain advantages and disadvantages. In this study the eligibility and performance of the Biolog phenotypic identification system (Biolog, Inc.) with GEN III microplates was tested. Parallel to this method, polymerase chain reaction with genus- and species-specific primers was performed. One hundred sixty-five isolates from nine types of artisan cheeses were isolated and analysed. Cheeses were produced from raw ewe's milk in Slovenia, Bosnia and Herzegovina, Croatia and Serbia. The Biolog phenotypic identification system identified 90 isolates, but only 55 identifications acquired by the Biolog system were supported by polymerase chain reaction at a genus level and 28 at a species level. The obtained results showed that the reliability of commercial phenotypic identification systems was inadequate when analysing lactic acid bacteria isolates from natural, spontaneous fermentations and needs to be additionally corroborated by genotypic identification methods.
\end{abstract}

Key words: microbial population, traditional cheese, phenotypic identification, microplate phenotypic system, species specific PCR

\section{Introduction}

Screening and identification of microbial community from traditional cheeses is important for maintenance of their biodiversity and specific characteristics. Because the use of starters has diminished the diversity, nowadays there is an interest in searching for potential new starter organisms among bacterial strains, isolated from artisanal cheeses. Together with the research in this field, a wide range of techniques were developed for successful microbial population analysis. These techniques can be divi- ded into three separate groups: cultivation methods followed by phenotypic characterisation, cultivation methods followed by molecular characterisation and cultivation-independent methods based on direct molecular characterisation and classification (Beresford et al., 2001). All of these approaches have certain advantages and disadvantages. The main disadvantage of classical phenotypic methods is the great time-consumption, yet, they provide information about micro-organisms' adaptations to certain environmental factors (Di Cagno et al., 2010). Today there are several rapid phenotypic identification 
systems available, which are suitable for routine microbial analysis. However, they lack reliability, when environmental and food samples with great strain variability are to be analysed. Dairy products and their production environment represent a specific ecological niche to which lactic acid bacteria (LAB) have adapted (van de Guchte et al., 2006). Analysing microbial population in traditional dairy products is usually difficult since most rapid commercial tests have been designed for detection and identification of clinical isolates (Truu et al., 1999). Nevertheless some semi-automated systems have been improved and adapted for LAB and application in the dairy environment. The Biolog system enables phenotypic identification at a species and also subspecies level. First it was designed for the identification of Gramnegative bacteria, but its range of use was eventually upgraded to enable identification of LAB and other Gram-positive organisms (Stager and Davis, 1992). The phenotypic fingerprint, obtained on a specific microplate after incubation, is compared with the fingerprints of known micro-organisms deposited as type strains in American Type Culture Collection (ATCC). Most of the published studies that used the Biolog system involve identification of pathogenic and other Gram-negative bacteria (Odumeru et al., 1999; Truu et al., 1999; Becker et al., 2009). The two published studies that dealt with LAB specifically used the Biolog system either to determine the metabolic profile of different Lactobacillus (Lb.) plantarum strains (Di Cagno et al., 2010) or to identify different Leuconostoc (Lc.) species (Tamang et al., 2008). It is rather difficult to obtain data that would clarify the usefulness and performance of the Biolog phenotypic identification system for identification of LAB.

The aim of this study was to test the performance of the Biolog phenotypic identification system on autochthonous LAB isolates from spontaneous fermentations of different traditional raw milk cheeses. To verify any potential misclassification, the results of phenotypic identification were also evaluated by the polymerase chain reaction (PCR) genotypic method with genus- and species-specific primers.

\section{Materials and methods}

\section{Cheese samples}

Nine artisanal cheeses produced from raw ewes' milk in four countries in the Western Balkans regions were analysed: Karst ewe's cheese, Dolenjski ewe's cheese and Bovški ewe's cheese from Slovenia; Paški ewe's cheese and Krčki ewe's cheese from Croatia; Pirotski ewe's cheese and Sjenički ewe's cheese from Serbia and Travnički ewe's cheese and Livanjski ewe's cheese from Bosnia and Herzegovina. Both cheeses from Serbia were white cheeses ripened in brine. Travnički cheese is a special hard type cheese also ripened in brine while other cheeses belonged to the group of classical hard type ewe's cheeses.

\section{Bacterial strains}

Bacterial strains were isolated from cheese samples by homogenising $10 \mathrm{~g}$ of cheese in $90 \mathrm{~mL} 2 \%$ (w/v) tri-sodium citrate di-hydrate solution (Kemika, Zagreb, Croatia) prepared according to IDF standard 122B:1992. Homogenisation in a Stomacher LabBlender (Bagmixer R400, Interscience, F-78860 St. Nom, France) was followed by diluting the samples in quarter-strength Ringer's solution (Merck, Darmstadt, Germany) and spreading them on to M17 (Merck, Darmstadt, Germany) and de Man, Rogosa and Sharpe agar plates (MRS, Merck). After incubation $\left(37^{\circ} \mathrm{C}, 48 \mathrm{~h}\right) 10$ colonies were randomly picked from each type of agar plate. From Pirotski cheese only isolates that grew on M17 agar plates were included because on MRS agar plates weren't any visible colonies. There were also difficulties with 5 isolates from Krčki cheese which were lost during purification. Because of a poor growth, the final number of isolates was 165 instead of 180. After purification, the isolates were stored at $-20{ }^{\circ} \mathrm{C}$ in MRS or M17 broth supplemented with $30 \%(\mathrm{w} / \mathrm{v})$ glycerol (Merck) until further characterisation.

\section{Phenotypic characterisation by Biolog system}

Randomly selected strains from MRS and M17 agar plates were identified using the Biolog system and GEN III microplates (Biolog, Inc., Hayward, USA) designed to identify pure cultures of Gramnegative and Gram-positive bacteria. The entire process of identification was performed according to 
manufacturer's instructions. In brief, before inoculation of the Biolog GEN III plates, the isolates were streaked once on MRS or M17 agar plates and twice on BUG agar plates (Biolog, Inc., Hayward, USA) and incubated at $33{ }^{\circ} \mathrm{C}$ for $24 \mathrm{~h}$. Based on a growth rate, oxygen and $\mathrm{CO}_{2}$ preferences of isolates to be identified, the Biolog system offers several different protocols or inoculation fluids to be used with GEN III microplates. In order to determine the most appropriate protocol, twenty isolates were analysed in parallel using two different protocols $(\mathrm{A}, \mathrm{Cl})$. The protocols $\mathrm{A}$ and $\mathrm{Cl}$ differ in the inoculation fluid. Of the two inoculation fluids, inoculation fluid $\mathrm{A}$ is easier to reduce and develop a colour reaction than inoculation fluid C. According to the manufacturer, protocol $\mathrm{A}$ is used for the vast majority of species while protocol $\mathrm{Cl}$ is used for slow growing microaerophilic and capnophilic Gram-positive cocci and tiny rods. Protocol Cl was selected as the most appropriate and has been used in majority of the samples. The wells of the Biolog GEN III plates were inoculated with $100 \mu \mathrm{L}$ of bacterial suspension, adjusted to $90-98 \%$ transmittance (protocol C1). After 22 and $48 \mathrm{~h}$ of incubation at $33^{\circ} \mathrm{C}$ the plates were read using a MicroStation plate reader and the results analysed with MICROLOG 3 Version 5.2.01 software.

The Biolog system evaluates all comparisons and makes the identification by calculating two different indexes. The SIM index represents how the metabolic profile of an unknown strain is similar to

Table 1. Genus- and species-specific primers used in PCR reactions and corresponding amplicon sizes

\begin{tabular}{|c|c|c|c|}
\hline Genus/Species & Primers & $\begin{array}{l}\text { Amplicon } \\
\text { size }\end{array}$ & References \\
\hline Enterococcus (Ent.) & $\mathrm{E} 1 / \mathrm{E} 2$ & 737 bp & Deasy et al., 2000 \\
\hline Ent. asini & AS1/ AS2 & $365 \mathrm{bp}$ & Jackson et al., 2004 \\
\hline Ent. casseliflavus & $\mathrm{CAl} / \mathrm{CA} 2$ & $288 \mathrm{bp}$ & Jackson et al., 2004 \\
\hline Ent. durans & DUl/ DU2 & 295 bp & Jackson et al., 2004 \\
\hline Ent. faecalis & ddl E. faecalis E1/ ddl E. faecalis E2 & $941 \mathrm{bp}$ & Dutka-Malen et al., 1995 \\
\hline Ent. faecium & ddl E. faecium F1/ ddl E. faecium F2 & $550 \mathrm{bp}$ & Dutka-Malen et al., 1995 \\
\hline Ent. gallinarum & GAl/ GA2 & $173 \mathrm{bp}$ & Jackson et al., 2004 \\
\hline Ent. hirae & HIl/ HI2 & $187 \mathrm{bp}$ & Jackson et al., 2004 \\
\hline Ent. villorum/porcinus & $\mathrm{PO} 1 / \mathrm{PO} 2$ & $280 \mathrm{bp}$ & Jackson et al., 2004 \\
\hline Lactobacillus (Lb.) & Lbl Mal-rev/ Rl6-1 & $250 \mathrm{bp}$ & Dubernet et al., 2002 \\
\hline Lb. casei & Y2/ CAS1 & $290 \mathrm{bp}$ & Ward and Timmins, 1999 \\
\hline Lb. bulgaricus & Lbl/ Llbl & $1065 \mathrm{bp}$ & Torriani et al., 1999 \\
\hline Lb. helveticus & LheI/ LheII & $500-650 \mathrm{bp}$ & Tilsala-Timisjärvi and Alatossava, 1997 \\
\hline Lb. paracasei & Y2/ Paral & $290 \mathrm{bp}$ & Ward and Timmins, 1999 \\
\hline Lb. plantarum & Lfpr/ PlanII & $200 \mathrm{bp}$ & Walter et al., 2000 \\
\hline Lb. rhamnosus & PrI/ RhaII & 186 bp & Walter et al., 2000 \\
\hline Lactococcus lactis & 27f/ Lla & $100 \mathrm{bp}$ & Barakat et al., 2000 \\
\hline $\begin{array}{l}\text { Leuconostoc } \\
\text { mesenteroides }\end{array}$ & Lmes-f/ Lmes-r & $1150 \mathrm{bp}$ & Lee et al., 2000 \\
\hline Pediococcus (P.) & Pedio23S_F/ Pedio23S_R & $701 \mathrm{bp}$ & Pfannebecker and Fröhlich, 2008 \\
\hline P. acidilactici & PAC23S_F/ P23S_R & $213 \mathrm{bp}$ & Collado et al., 2009 \\
\hline Staphylococcus (Staph.) & STA I/ STA II & $100-200 \mathrm{bp}$ & Forsman et al., 1997 \\
\hline Streptococcus (Str.) & STR I/ STR II & $150-210 \mathrm{bp}$ & Forsman et al., 1997 \\
\hline Str. thermophilus & ThI/ ThII & 205-304 bp & Tilsala-Timisjärvi and Alatossava, 1997 \\
\hline
\end{tabular}

bp - base pair 
Table 2. Identification results obtained with Biolog system for isolates from Karst ewe's cheese

\begin{tabular}{|c|c|c|c|}
\hline \multicolumn{4}{|c|}{ Karst ewe's cheese } \\
\hline \multicolumn{2}{|c|}{ isolates from M17 } & \multicolumn{2}{|c|}{ isolates from MRS } \\
\hline after 22 hours & after 48 hours & after 22 hours & after 48 hours \\
\hline Lac. lactis subsp. lactis & Lac. lactis subsp. lactis & Lb. pentosus* & Lactobacillus/Lb. pentosus* \\
\hline Lac. lactis subsp. lactis & Lac. lactis subsp. lactis & Lb. plantarum* & Lb. plantarum \\
\hline Ent. faecalis & Ent. faecalis* & Lactobacillus/Lb. plantarum* & Lb. plantarum* \\
\hline Ent. faecalis & Ent. faecalis & Lb. plantarum* & Lb. plantarum* \\
\hline Ent. faecalis & Ent. faecalis* & Lb. plantarum* & Lactobacillus/Lb. plantarum* \\
\hline Ent. faecalis & Ent. faecalis* ${ }^{*}$ & Lb. plantarum* & Lb. plantarum \\
\hline Ent. haemoperoxidus & Lac. lactis subsp. lactis & Lb. plantarum* & Lb. plantarum* \\
\hline Lac. lactis subsp. lactis & Lac. lactis subsp. lactis & Lb. plantarum* & Lb. plantarum \\
\hline Enterococcus & Enterococcus & Lb plantarum* & Lb. plantarum \\
\hline Lac. lactis subsp. lactis & Lac. lactis subsp. lactis & Lb. alimentarius* & Lb plantarum ${ }^{*}$ \\
\hline
\end{tabular}

* - most probable identification

the one deposited in the Biolog database under certain identification. The second index (DIST) represents the distance between the unknown strain and proposed identifications. When identification is made, both indexes are also used by the system to evaluate the probability of correct identification. Based on these calculations some isolates analysed in this study were not identified with enough certainty and were only described as most probable.

\section{Genotypic characterisation by genus and species specific PCR}

The Biolog phenotypic method was used as a screening method which pointed the way for basic selection of primers and grouped individual isolates together based on their metabolic profile. After initial phenotypic screening by the Biolog system, PCR was used to confirm the identifications of LAB or analyse the strains for some other, related genera or species. Because the focus was on LAB, eleven isolates (out of 165) stayed unidentified with oligonucleotide primers used in this trial.

DNA was extracted from pure MRS and M17 cultures using the Wizard ${ }^{\circledR}$ Genomic DNA Purification Kit (Promega, Madison, WI, USA). Genus- and species-specific primers for DNA amplifications were selected on the basis of preliminary identification with the Biolog system. All PCR mixtures and programmes were carried out according to the instructions of cited authors (Table 1). PCR amplifica- tion products were analysed on $1.8 \%$ agarose gels (100 V, 1 h), stained with SYBR Safe (Invitrogen, Oregon, USA) and visualised under a UV transilluminator. The molecular weight of the amplified DNA was estimated by comparison with GeneRuler $^{\text {TM }} 100$ bp DNA Ladder (Fermentas International Inc., Lithuania).

\section{Results and discussion}

One hundred and sixty five colonies from nine different cheese samples were isolated and purified. The Biolog identification system with GEN III microplates proved to be easy to use and allowed us to quickly process all 165 isolates. The first problem we encountered with this method involved the flexible time of incubation required to obtain a positive identification. We read the metabolic profile and made the identifications using the MicroStation analysis tool after 22 and $48 \mathrm{~h}$ of incubation. Of 165 isolates analysed in this study, only 90 isolates were identified identically after the first and second incubation periods. In cases when the metabolic profiles and identifications made were not identical, each identification was evaluated as a possibly correct one. Fifty-one percent of isolates were successfully identified at a species level, while $4 \%$ of isolates were identified only at genus level. Fortyfour percent of isolates analysed in this study were not identified with enough certainty and were only described as most probable. For $1 \%$ of isolates, the 
Table 3. Compliance of two types of the Biolog system's identifications with PCR results

\begin{tabular}{|c|c|c|c|c|c|c|}
\hline \multicolumn{2}{|c|}{$\begin{array}{l}\text { number of isolates used in } \\
\text { PCR after identification } \\
\text { with Biolog system }\end{array}$} & $\begin{array}{l}\text { number of } \\
\text { isolates in each } \\
\text { group }\end{array}$ & group & $\begin{array}{l}\text { confirmed } \\
\text { identification } \\
\text { by PCR in } \% \\
\text { for defined }\end{array}$ & $\begin{array}{l}\text { not confirmed } \\
\text { identification } \\
\text { by PCR in \% for } \\
\text { defined group }\end{array}$ & $\begin{array}{c}\text { not } \\
\text { determined } \\
{[\%]}\end{array}$ \\
\hline \multirow{4}{*}{ 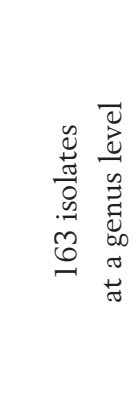 } & \multirow{4}{*}{ 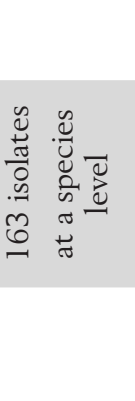 } & 90 & $\begin{array}{l}\text { identifications at } \\
\text { a genus level }\end{array}$ & 61 & 27 & 12 \\
\hline & & 84 & $\begin{array}{l}\text { identifications at } \\
\text { a species level }\end{array}$ & 33 & 49 & 18 \\
\hline & & 79 & $\begin{array}{l}\text { probable iden- } \\
\text { tifications at a } \\
\text { species level }\end{array}$ & 17 & 59 & 24 \\
\hline & & 73 & $\begin{array}{l}\text { probable identifi- } \\
\text { cations at a genus } \\
\text { level }\end{array}$ & 64 & 17 & 19 \\
\hline
\end{tabular}

system was unable to yield any identification at all. Table 2 presents the results obtained with Biolog system for one of the cheeses with best identifications at species level.

Various identification protocols, proposed by the manufacturer, were essayed but all of these protocols had low identification success rate. For most samples, protocol $\mathrm{Cl}$ was selected as the most appropriate with the exception of some samples of Lactobacillus species where protocol C2 was used. Protocol C2 differs from protocol Cl only in inoculation density.

In parallel with identification by the Biolog system, identifications using the molecular PCR method with genus- and species-specific oligonucleotide primers were preformed (Table 3 ). The strains analysed by the PCR method were separated into two groups based on the level of identification made by the Biolog system. The first group is represented by 90 isolates for which the Biolog system was able to make the identification, while a group of 73 isolates represents a group for which the metabolic profile was not clear enough to make the identification and was only suggested as the most probable one. Table 3 represents the results of the PCR method analysis of strains within both groups.

Within the first group of isolates, the identifications obtained by the Biolog system were confirmed with the PCR method at a genus level in $61 \%$ of cases and in $33 \%$ of cases at a species level. Different identifications at a genus level were ob- tained for $27 \%$ of isolates and at a species level for 49 $\%$ of the isolates. In table 4 are gathered most common identifications obtained by Biolog system and their confirmation with PCR. It has been shown that strains possessing familiar phenotypes don't always have similar or even remotely related genotype which presents a problem when employing identification methods based on phenotypic features. Temmerman et al. (2004) suggested several phenotypic methods to be used at once so the disadvantages of one method are compensated by another, but this presents a costly and time-consuming approach.

When the second group of isolates was evaluated by the PCR method, $64 \%$ of these most probable identifications were in accordance at a genus level and $17 \%$ at a species level. Different identifications were obtained in $17 \%$ of cases at a genus level and in $59 \%$ of cases at a species level. Both groups of isolates also included a larger share of strains whose identifications and probable identifications could not be analysed by set of oligonucleotide primers used in this study. These include genera Corynebacterium, Micrococcus, Bacillus, Eikenella, Erysipelothrix, Dermobacter, Cellulomonas, Sanguibacter, Listeria, Microbacterium, Gardenerella and Actinomyces. The results represented in Table 3 show that both groups of strains were identified with a similar reliability at a genus level even though the Biolog system designates the strains from the second group as uncertain. 
Table 4. Most common identifications obtained by Biolog system and confirmation/different identification with PCR method

\begin{tabular}{|c|c|c|}
\hline Genus/Species & Biolog system & PCR \\
\hline Lactobacillus & $*$ & $\checkmark$ \\
\hline Lb. plantarum & $*$ & $\checkmark$ \\
\hline Lb. rhamnosus & $*$ & $\times$, Lb. paracasei \\
\hline Lb. coryniformis & $*$ & - \\
\hline Lb. jensenii & $*$ & Lb. casei \\
\hline Lb. brevis & $*$ & - \\
\hline Lb. pentosus & * & Lb. plantarum \\
\hline Lb. hamsteri & $*$ & Lb. plantarum \\
\hline Lb. sake & $*$ & Lb. casei \\
\hline Weissella viridescens & $\checkmark$ & Lb. paracasei \\
\hline Enterococcus & $\checkmark$ & $\checkmark$ \\
\hline Ent. faecalis & $\checkmark$ & $\checkmark$ \\
\hline Ent. casseliflavus & $*$ & $x$ \\
\hline Ent. faecium & $*$ & $\checkmark$ \\
\hline Ent. durans & $*$ & $\checkmark$ \\
\hline Ent. pseudoavium & $\checkmark$ & - \\
\hline Ent. asini & $*$ & $\checkmark$ \\
\hline Ent. gallinarum & $\checkmark$ & $\checkmark$ \\
\hline Ent. hirae & $*$ & $x$ \\
\hline Ent. haemoperoxidus & $*$ & - \\
\hline Ent. villorum & $*$ & $x$ \\
\hline Lactococcus lactis & $\checkmark$ & $\checkmark$ \\
\hline Streptococcus & $\checkmark$ & $\checkmark$ \\
\hline Str. bovis & $\checkmark$ & Str. thermophilus \\
\hline Str. vestibularis & $\checkmark$ & Str. thermophilus \\
\hline Str. gallolyticus & $\checkmark$ & - \\
\hline Staphylococcus & $*$ & $\checkmark$ \\
\hline Staph. hominis & $\checkmark$ & - \\
\hline Staph. capitis & $\checkmark$ & - \\
\hline Staph. haemolyticus & $\checkmark$ & - \\
\hline Leuconostoc lactis & $*$ & Leuconostoc mesenteroides \\
\hline Pediococcus & $*$ & $\checkmark$ \\
\hline P. acidilactici & $*$ & $x$ \\
\hline P. pentosaceus & $*$ & - \\
\hline
\end{tabular}

$\checkmark$ successful identification with Biolog system / positive confirmation with PCR, * most probable identification with Biolog system,

$x$ different identification with PCR, - not determined with PCR

Of all isolates identified using the Biolog system, most (38\%) were identified as members of the genus Lactobacillus (Figure 1), the major representative being species $L b$. plantarum. Complemen- tary results of prevailing microbial community were obtained with PCR, but there was a larger portion of unidentified samples. Unidentified samples were mostly a consequence of mismatched results with 
Figure 1. A: Microbial community (in \%) of analysed cheeses obtained with Biolog system; B: Microbial community (in \%) of analysed cheeses obtained with PCR method

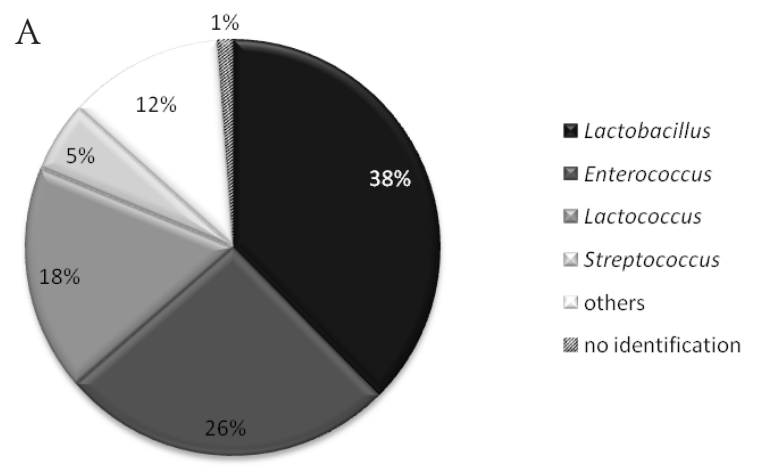

Biolog system. PCR was left out for some bacterial strains that were identified with Biolog system in smaller numbers and are not typical for cheese microbiota. A smaller portion of isolates were identified as Weissella viridescens by the Biolog system but later on identified as members of the $L b$. paracasei group by the PCR method. Genus Weissella $(W$.$) is closely related to Lactobacillus (Huys et$ al., 2012), with a similar metabolic profile which is probably the reason why strains of $L b$. paracase $i$ group were always identified as $W$. viridescens.

Members of the $L b$. paracasei group were expected to be well represented within the genus Lactobacillus according to the literature for cheeses made from ewes' milk (Di Cagno et al., 2003; Čanžek Majhenič et al., 2007). Both genera Lactobacillus and Enterococcus (Ent.) are predominant representatives in artisan raw milk cheeses from the Western Balkans area (Čanžek Majhenič et al., 2005; Pogačić et al., 2011; Radulović et al., 2012). This was also shown in this study; $26 \%$ of isolates were identified as genus Enterococcus and within this genus species Ent. faecalis was the most frequently identified. All the other genera identified in this study by the Biolog system were also in accordance with current literature describing microbial composition of traditional cheeses (LitopoulouTzanetaki and Tzanetakis 2011; Golić et al., 2013; Ordiales et al., 2013). Species Lactococcus lactis was identified in $18 \%$ of analysed isolates, followed by genera Streptococcus (5\%), Staphylococcus (3\%), Pediococcus (2 \%) and Corynebacterium (2\%). Other identified genera represented with one or two isolates were Leuconostoc, Micrococcus, Bacillus, Eikenella, Erysipelothrix, Dermobacter,

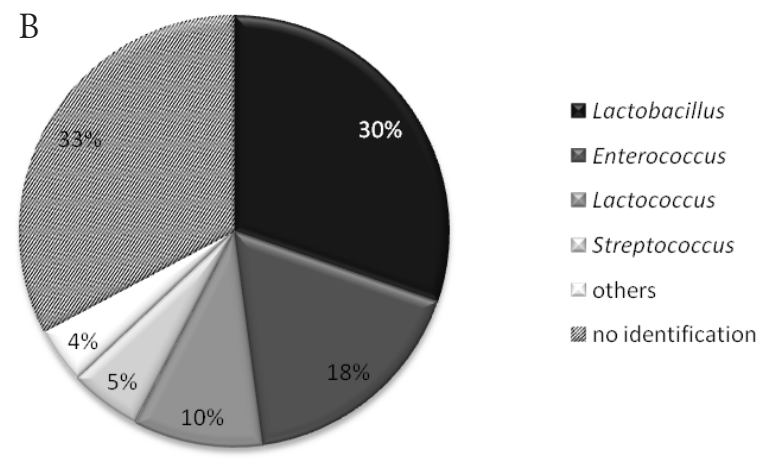

Cellulomonas, Sanguibacter, Listeria, Microbacterium, Gardenerella and Actinomyces.

\section{Conclusions}

Appropriate choice of identification method is crucial for the studies of microbial community included in the fermentation process and is dependent on many factors, particularly on the origin and number of samples. The Biolog system was chosen for identification due to its simplicity and its ability to simultaneously analyse a large number of isolates. Although it was possible to obtain a rough picture of the present microbial population, the Biolog system is still not reliable enough to be used as the only method for identification of bacteria that originate from complex natural samples like raw milk cheese. Rapid and high-throughput methods are preferred thus PCR based methods are the most widely used for the identification of unknown strains. Employing PCR with genus- and species-specific oligonucleotide primers is not particularly suitable as a screening method when dealing with a large number of isolates. In this case, combining both phenotypic and genotypic methods for identification proved to be the right way of choice. The single strain isolates that were eventually left unidentified or unconfirmed could be processed by some more sophisticated molecular method like sequencing of $16 \mathrm{~S}$ rRNA gene or $16 \mathrm{~S} / 23 \mathrm{~S}$ spacer region. 


\section{PCR provjera identifikacija fenotipskog sistema s mikropločama za $B M K$ iz tradicionalnih sireva od sirovog mlijeka sa Zapadnog Balkana}

\section{Sažetak}

Fermentacija i specifično zrenje sira najvećim je dijelom uvjetovano prirodnom mikrobnom zajednicom prisutnom u mlijeku, a koja se selekcionira uz pomoć sirarskog okoliša i tehnologije. Stoga su tradicionalni sirevi unikatni proizvodi sa specifičnom mikrobnom bioraznolikošću. Postoje različite mogućnosti identifikacije mikrobne populacije, međutim svi pristupi imaju svoje prednosti i nedostatke. U ovom istraživanju testirana je prikladnost i učinkovitost fenotipskog identifikacijskog sustava Biolog (Biolog, Inc.) s GEN III mikropločama. Usporedno je izvođena lančana reakcija polimeraze s rodom i vrstom specifičnih početnica. $\mathrm{U}$ ovom je istraživanju izolirano $\mathrm{i}$ analizirano ukupno 165 izolata porijeklom od devet vrsta tradicionalnih sireva. Sirevi su bili proizvedeni od sirovog ovčjeg mlijeka u Sloveniji, Bosni i Hercegovini, Hrvatskoj i Srbiji. Fenotipski identifikacijski sustav Biolog identificirao je 90 izolata. 55 identifikacija bilo je potvrđeno metodom lančane reakcije polimeraze na razini roda, a 28 na razini vrsta. Rezultati su pokazali da je pouzdanost komercijalnog fenotipskog identifikacijskog sistema neadekvatna kada se analiziraju izolati mliječno kiselinskih bakterija prirodnih i spontanih fermentacija. Taj identifikacijski sistem potrebno je dodatno potvrditi genotipskim identifikacijskim metodama.

Ključne riječi: mikrobna populacija, tradicionalni sir, fenotipska identifikacija, fenotipski sistem sa mikropločama, za vrstu specifične PCR

\section{Acknowledgements}

The research presented in this paper was conducted within the framework of the SEE-ERA.NET project called "Characterisation and tracking the origin of specific features of traditional cheeses in the Western Balkans Region" (Acronym: RegTraC; Project ID: ERA 133).

\section{Disclaimer}

The views expressed in this publication are the sole responsibility of the author(s) and do not necessarily reflect the views of the European Commission. Neither the European Commission nor any person acting on behalf of the Commission is responsible for the use which might be made of the information contained herein.

\section{References}

1. Barakat, R.K., Griffiths, M.W., Harris, L.J. (2000): Isolation and characterisation of Carnobacterium, Lactococcus and Enterococcus spp. from cooked, modified atmosphere packaged, refrigerated, poultry meat. International Journal of Food Microbiology 62 (1-2), 83-94. doi: dx.doi.org/10.1016/S0168-1605(00)00381-0

2. Becker, B., Weiss, C., Holzapfel, W.H. (2009): An evaluation of the use of three phenotypic test-systems for biochemical identification of Enterobacteriaceae and Pseudomonadaceae. Food Control 20 (9), 815-821. doi: dx.doi.org/10.1016/j.foodcont.2008.10.014

3. Beresford, T.P., Fitzsimons, N.A., Brennan, N.L., Cogan, T.M. (2001): Recent advances in cheese microbiology. International Dairy Journal 11, 259-274. doi: dx.doi.org/10.1016/S0958-6946(01)00056-5

4. Collado, M.C., Delgado, S., Maldonado, A., Rodriguez, J.M. (2009): Assessment of the bacterial diversity of breast milk of healthy women by quantitative real-time PCR. Letters of Applied Microbiology, 48 (5), 523-528. doi: dx.doi.org/10.1111/j.1472-765X.2009.02567.x

5. Čanžek Majhenič, A., Mohar Lorberg, P., Rogelj, I. (2007): Characterization of the Lactobacillus community in traditional Karst ewe's cheese. Society of Dairy Technology 60 (3), 182-190. doi: dx.doi.org/10.1111/j.1471-0307.2007.00336.x

6. Čanžek Majhenič, A., Rogelj, I., Perko, B. (2005) Enterococci from Tolminc cheese: population structure, antibiotic susceptibility and incidence of virulence determinants. International Journal of Food Microbiology 102, 239-244. doi: dx.doi.org/10.1016/j.ijfoodmicro.2004.12.021

7. Deasy, B.M., Rea, M.C., Fitzgerald, G.F., Cogan, T.M., Beresford, T.P. (2000): A rapid PCR based method to distinguish between Lactococcus and Enterococcus. Systematic and Applied Microbiology 23, 510-522. doi: dx.doi.org/10.1016/S0723-2020(00)80025-9

8. Di Cagno, R., Banks, J., Sheehan, L., Fox, P.F., Brechany, E.Y., Corsetti, A., Gobbetti, M. (2003): Comparison of the microbiological, compositional, biochemical, volatile profile and sensory characteristics of three Italian PDO ewes' milk cheeses. International Dairy Journal 13, 961-972. doi: dx.doi.org/10.1016/S0958-6946(03)00145-6

9. Di Cagno, R., Minervini, G., Sgarbi, E., Lazzi, C., Bernini, V., Neviani, E., Gobbetti, M. (2010): Comparison of phenotypic (Biolog System) and genotypic (random amplified polymorphic DNA-polymerase chain reaction, RAPD-PCR, and amplified fragment length polymorphism, AFLP) methods for typing Lactobacillus plantarum isolates from raw vegetables and fruits. International Journal of Food Microbiology 143, 246-253. doi: dx.doi.org/10.1016/j.ijfoodmicro.2010.08.018 
10. Dubernet, S., Desmasures, N., Gueguen, M. (2002): A PCR-based method for identification of lactobacilli at the genus level. FEMS Microbiology Letters 214, 271-275. doi: dx.doi.org/10.1111/j.1574-6968.2002.tb11358.x

11. Dutka-Malen, S., Evers, S., Courvalin, P. (1995): Detection of glycopeptide resistance genotypes and identification of the species level of clinically relevant enterococci by PCR. Journal of Clinical Microbiology 33 (1), 24-27.

12. Forsman, P., Tilsala-Timisjärvi, A., Alatossava, T. (1997): Identification of staphylococcal and streptococcal causes of bovine mastitis using 16S-23S rRNA spacer regions. Microbiology 143, 3491-3500. doi: dx.doi.org/10.1099/00221287-143-11-3491

13. Golić, N., Čadež, N., Terzić-Vidojević, A., Šuranská, H., Beganović, J., Lozo, J., Kos, B., Šušković, J., Raspor, P., Topisirović, L. (2013): Evaluation of lactic acid bacteria and yeast diversity in traditional white pickled and fresh soft cheeses from mountain regions of Serbia and lowland regions of Croatia. Journal of Food Microbiology 166, 294-300. doi: dx.doi.org/10.1016/j.ijfoodmicro.2013.05.032

14. Huys, G., Leisner, J., Björkroth, J. (2012): The Lesser LAB Gods: Pediococcus, Leuconostoc, Weissella, Carnobacterium, and Affiliated Genera. IN Lahtinen, S., Ouwehand, A.C., Salminen, S., Von Wright, A. (Eds.) Lactic acid bacteria. Microbiological and functional aspects. $4^{\text {th }}$ edn., CRC Press.

15. Jackson, C.R., Fedorka-Cray, P.J., Barrett, J.B. (2004): Use of a genus- and species- specific multiplex PCR for identification of enterococci. Journal of Clinical Microbiology 42 (8), 3558-3565. doi: dx.doi.org/10.1128/JCM.42.8.3558-3565.2004

16. Lee, H.-J., Park, S.-Y., Kim, J. (2000): Multiplex PCR-based detection and identification of Leuconostoc species. FEMS Microbiology Letters 193, 243-247. doi: dx.doi.org/10.1111/j.1574-6968.2000.tb09431.x

17. Litopoulou-Tzanetaki, E., Tzanetakis, N. (2011): Microbiological characteristics of Greek traditional cheeses. Small Ruminant Research 101, 17-32. doi: dx.doi.org/10.1016/j.smallrumres.2011.09.022

18. Odumeru, J.A., Steele, M., Fruhner, L., Larkin, C., Jiang, J., Mann, E., McNab, W.B. (1999): Evaluation of accuracy and repeatability of identification of food-borne pathogens by automated bacterial identification systems. Journal of Clinical Microbiology 37 (4), 944-949.

19. Ordiales, E., Benito, M.J., Martín, A., Casquete, R., Serradilla, M.J., Córdoba, M.G. (2013): Bacterial communities of the traditional raw ewe's milk cheese "Torta del Casar" made without the addition of a starter. Food Control 33, 448-454. doi: dx.doi.org/10.1016/j.foodcont.2013.03.027

20. Pfannebecker, J., Fröhlich, J. (2008): Use of a species-specific multiplex PCR for the identification of pediococci. International Journal of Food Microbiology 128 (2), 288-296. doi: dx.doi.org/10.1016/j.ijfoodmicro.2008.08.019

21. Pogačić, T., D'Andrea, M., Kagkli, D.-M., Corich, V., Giacomini, A., Baldan, E., Čanžek Majhenič, A., Obermajer, T., Rogelj, I., Samaržija, D. (2011): Biodiversity of microbial consortia isolated from traditional fresh sheep cheese Karakačanski skakutanac. Mljekarstvo 61 (3), 208-219.
22. Radulović, Z., Mirković, N., Petrušić, M., Barać, M., Paunović D., Obradović, D. (2012): Lactic Acid Bacteria Isolated from Artisanal Sheep Kashkaval Cheese. Special Issue of the International Dairy Federation 1201: IDF International Symposium on Sheep, Goat and other nonCow milk, Athens, Greece, 112-115.

23. Stager, C.E., Davis, J.R. (1992): Automated systems for identification of microorganisms. Clinical Microbiology Reviews 5, 302-327.

24. Tamang, B., Tamang, J.P., Schillinger, U., Franz, C.M., Gores, M., Holzapfel, W.H. (2008): Phenotypic and genotypic identification of lactic acid bacteria isolated from ethnic fermented bamboo tender shoots of North East India. International Journal of Food Microbiology 121 (1), 35-40. doi: dx.doi.org/10.1016/j.ijfoodmicro.2007.10.009

25. Temmerman, R., Huys, G., Swings, J. (2004): Identification of lactic acid bacteria: culturedependent and culture-independent methods. Trends in Food Science \& Technology 15, 348-359. doi: dx.doi.org/10.1016/j.tifs.2003.12.007

26. Tilsala-Timisjärvi, A., Alatossava, T. (1997): Development of oligonucleotide primers from the 16S-23S rRNA intergenic sequences for identifying different dairy and probiotic lactic acid bacteria by PCR. International Journal of Food Microbiology 35 (1), 49-56. doi: dx.doi.org/10.1016/S0168-1605(97)88066-X

27. Torriani, S., Zapparoli, G., Dellaglio, F. (1999): Use of PCR-based methods for rapid differentiation of Lactobacillus delbrueckii subsp. bulgaricus and L. delbrueckii subsp. lactis. Applied and Environmental Microbiology 65 (10), 4351-4356.

28. Truu, J., Talpsep, E., Heinaru, E., Stottmeister, U., Wand, H., Heinaru, A. (1999): Comparison of API 20NE and Biolog GN identification systems assessed by techniques of multivariate analyses. Journal of Microbiology Methods 36 (3), 193-201. doi: dx.doi.org/10.1016/S0167-7012(99)00030-5

29. van de Guchte, M., Penaud, S., Grimaldi, C., Barbe, V., Bryson, K., Nicolas, P., Robert, C., Oztas, S., Mangenot, S., Couloux, A., Loux, V., Dervyn, R., Bossy, R., Bolotin, A., Batto, J.-M., Walunas, T., Gibart, J.-F., Bessieres, P., Weissenbach, J., Ehrlich, S.D., Maguin, E. (2006): The complete genome sequence of Lactobacillus bulgaricus reveals extensive and ongoing reductive evolution. Proceedings of the $\mathrm{Na}$ tional Academy of Science USA 103 (24), 9274-9279. doi: dx.doi.org/10.1073/pnas.0603024103

30. Walter, J., Tannock, G.W., Tilsala-Timisjärvi, A., Rodtong, S., Loach, D.M., Munro, K., Alatossava, T. (2000): Detection and identification of gastrointestinal Lactobacillus species by using denaturing gradient gel electrophoresis and species-specific PCR primers. Applied and Environmental Microbiology 66 (1), 297-303. doi: dx.doi.org/10.1128/AEM.66.1.297-303.2000

31. Ward, L.J.H., Timmins, M.J. (1999): Differentiation of Lactobacillus casei, Lactobacillus paracasei and Lactobacillus rhamnosus by polymerase chain reaction. Letters of Applied Microbiology 29, 90-92. doi: dx.doi.org/10.1046/j.1365-2672.1999.00586.x 